\title{
Evaluation of Knowledge and Preparedness Among Indian Dentists During the Current COVID-19 Pandemic: A Cross-Sectional Study
}

This article was published in the following Dove Press journal: Journal of Multidisciplinary Healthcare

\author{
Suraj Arora' \\ Shahabe Abullais Saquib ${ }^{2}$ \\ Nilofar Attar (D) ${ }^{3}$ \\ Sandeep Pimpale ${ }^{4}$ \\ Khwaja Saifullah Zafar ${ }^{5}$ \\ Priyanka Saluja (iD ${ }^{6}$ \\ Anshad M Abdulla ${ }^{7}$ \\ Shaheen Shamsuddin (iD) \\ 'Department of Restorative Dental \\ Sciences, College of Dentistry, King \\ Khalid University, Abha 61321, Saudi \\ Arabia; ${ }^{2}$ Periodontics and Community \\ Dental Sciences, College of Dentistry, \\ Research Center for Advanced Materials \\ Science, King Khalid University, Abha \\ 61321, Saudi Arabia; ${ }^{3}$ Department of \\ Periodontics, Government Dental \\ College and Hospital, Mumbai, \\ Maharashtra, India; ${ }^{4}$ Department of \\ Periodontics, Nair Dental College and \\ Hospital, Mumbai, Maharashtra, India; \\ ${ }^{5}$ Department of Basic Medical Sciences \\ (Emergency Medical Service), College of \\ Applied Medical Sciences, King Khalid \\ University, Abha 6132I, Saudi Arabia; \\ ${ }^{6}$ Department of Conservative Dentistry \\ and Endodontics, JCD Dental College \\ Vidyapeeth, Sirsa, Haryana 125055, India; \\ ${ }^{7}$ Department of Pediatric Dentistry \& \\ Orthodontics, College of Dentistry, King \\ Khalid University, Abha 6I32I, Kingdom \\ of Saudi Arabia; ${ }^{8}$ Orthodontics and \\ Dentofacial Orthopedics, Department of \\ Preventive Dental Sciences, College of \\ Dentistry, King Khalid University, Abha \\ 61321, Kingdom of Saudi Arabia
}

Correspondence: Priyanka Saluja Department of Conservative Dentistry and Endodontics, JCD Dental College Vidyapeeth, Sirsa 125055, Haryana, India $\mathrm{Tel}+919463872774$

Email priyanka.salujaarora@gmail.com
Purpose: The current scenario of the COVID-19 pandemic has forced dentists to prepare themselves by updating their knowledge and receive training to face the present and after effects of COVID-19. The present survey was thus conducted to assess the knowledge, risk perception, attitude, and preparedness of the dentists in India about COVID-19.

Materials and Methods: A cross-sectional online survey was carried out among registered dentists in India. A self-administered, anonymous, questionnaire comprising of 25 closeended questions was circulated to gather the relevant information. A total of 765 dentists submitted a response, out of which 646 complete responses were included in the statistical analysis. Pearson's Chi-square test was used for inter-group statistical comparison.

Results: The majority $(80.8 \%)$ of the dentists had a fair knowledge about the characteristics of COVID-19. Nearly $60.7 \%$ and $49.7 \%$ of the dentists had taken infection control training and special training for COVID-19, respectively. Nearly $50 \%$ of the dentists had the perception that COVID-19 is very dangerous. Only $41.8 \%$ of the dentists were willing to provide emergency services to patients. Most of the dentists had an opinion that there is a need to enhance personal protective measures. During the survey, it was found that varied technological advances are offered to dentists to ensure good clinical practice. They also concurred that there was a need to standardize the tools and measures available to carry out dental practices.

Conclusion: In the present study, Indian dentists have presented satisfactory knowledge with adequate preparedness as the majority of them had a fair level of knowledge with significantly higher knowledge among female respondents and those with post-graduation studies. Dentists should make judicious utilization of all the precautionary measures to safely practice dentistry. As we are going through an evolutionary phase where new advances are expected to evolve, dentists will definitely emerge successfully out from the crisis of the COVID-19 pandemic.

Keywords: corona virus, healthcare workers, dentistry, Asian, awareness

\section{Introduction}

In Wuhan city in the People's Republic of China, on December 30, 2019, multiple cases of pneumonia of unknown etiology were identified. WHO named it as COVID-19 and declared it as a public health emergency of international concern because of it's highly infectious nature. ${ }^{1}$ COVID-19 is caused due to SARS-CoV-2 virus which is a single-stranded RNA with protein spike, envelope membrane, and nucleic capsid. ${ }^{2}$ In most of the cases, the average incubation period is of 4-14 days. ${ }^{3}$ The clinical symptoms are varied and manifest as fever, nasal congestion, 
headache, cough, sore throat, shortness of breath, nausea, vomiting, and diarrhea. ${ }^{4}$ COVID-19 is spread among humans through all kinds of droplet infection including through sneezing and coughing. ${ }^{5}$

COVID-19 has so far affected a large number of health professionals around the world. ${ }^{6}$ Since the dentist works in close proximity to body fluids such as saliva and blood in the oral cavity; they are at a high risk to get infected. ${ }^{7}$ The emergence of COVID-19 made us realize that even though we have been working in the field of dentistry and handling clinical cases with HIV, hepatitis, tuberculosis, and other infectious diseases, we were never prepared for a pandemic with such a high impact on community health.

Severe acute respiratory syndrome (SARS) in 2003 reported that no dental health worker or a patient had contracted the virus in a dental setting. It was unlikely that patients with SARS could visit a dental clinic in the acute phase because of high fever. The applications of universal precautionary measures were found to be adequate for infection control. ${ }^{8}$ However, COVID-19 is highly infectious as it is even spreading through asymptomatic contact. The presence of virus in saliva $(91.7 \%$ of patients) makes the dentist extremely vulnerable to contract the disease. ${ }^{9}$

Dentists work in an environment of aerosol and splatter. The airborne material can spread at a distance of eighteen-inches from the operator site. ${ }^{10}$ To protect the dental community, the American Dental Association has issued guidelines to suspend elective or planned dental treatment and carry out only emergency procedures. ${ }^{11}$ To have minimal or no contact with patients, telemedicine or telephonic communication is being advised. ${ }^{12}$ Dentists are in a state of psychological distress and fear while working in such an unprecedented situation. ${ }^{13,14}$ Dentists, among various health professionals, fall at the highest risk of contracting an infection. ${ }^{15}$ Dentistry is undergoing a phase where there is a need to enhance and improvise the way of practice. This survey was conducted to assess the awareness and knowledge about COVID-19 among dental professionals. The present survey also assessed the preparedness of dental professionals towards managing and treating patients in the present crisis.

\section{Materials and Methods}

This prospective, cross-sectional study was carried out from June 1, 2020 to June 8, 2020. This study was conducted among dentists in India, including those doing post-graduation studies, general and specialist dentists working in government, private and other health sectors. A self-explanatory, online questionnaire comprised of 25 closed-ended questions was prepared using Google forms to assess knowledge, attitude, and preparedness of COVID-19 among Indian dentists.

The questionnaire was designed in the English language and was categorized into four parts: 1) demographics and general characteristics (8 items) of the participants; 2) knowledge (10 items) of the participants about COVID-19; 3) Risk perception and attitude (10 items) of the participants about COVID-19; and 4) Preparedness (5 items) of the participants against COVID-19. A pilot study was performed on 30 randomly selected dentists before starting the collection of actual data figures. The pilot samples were not included in the final sample size. The main purpose of the pilot survey was to ensure the validity and reliability of the questionnaire; to find out any hurdle while collecting the data; to evaluate time duration required in filling the form and obtaining suggestions from the participants to overcome the obstacles. The face and content validity of the questionnaire was thoroughly assessed and evaluated for readability, clarity and comprehensiveness of the questions by the subject and research experts. The questionnaire was modified according to the reviewer comments before the final approval. Cronbach's alpha test was used to assess the reliability of the questionnaire. Cronbach's alpha value for knowledge segment and attitude segment were 0.853 and 0.812 , respectively, which indicated that the questionnaire was well-structured and suitable for the selected population. Knowledge score was calculated by awarding " 1 " point for each positive/correct response and " 0 " points for each negative/wrong response. The final scores were presented in the form of percentage by adding all the points of the respondents followed by calculating the percentage. The calculated knowledge score was divided into three categories based on percentage: poor knowledge ($0-40 \%)$, fair knowledge $(41<70 \%)$ and good knowledge (70\% and above). ${ }^{16}$

The study proposal was addressed to the Institutional Ethics Committee (IEC) and ethical clearance (2020-3645) was obtained. The link of the questionnaire along with a consent form was forwarded to the contacts of the researchers using e-mails and various social media platforms. From all over India, 765 dentists were randomly selected for voluntary participation. The confidentiality of information was preserved during the process by keeping it anonymous and requesting the participants for honest 
answers. Data was collected in an organized manner from dentists working in various health sectors across different states in India.

The data on categorical variables are shown as $n(\%$ of respondents - prevalence) and the data on continuous variables is presented as mean and standard deviation (SD). The inter-group statistical comparison of the distribution of categorical variables was tested using Pearson's Chi-square test. In the entire study, $P$-values less than 0.05 were considered to be statistically significant. The entire data was statistically analyzed using Statistical Package for Social Sciences (SPSS ver 22.0, IBM Corporation, USA) for MS Windows.

\section{Results}

\section{Distribution of Demographic Parameters}

A total of 765 respondents submitted the form, out of which $646(84.4 \%)$ complete responses were included for the statistical analysis. Of the 646 respondents, 350 (54.2\%) were male and $296(45.8 \%)$ were female. The majority of the respondents, 303 (46.9\%) had an age range of 30-39 years. While considering the duration of practice, only $100(15.5 \%)$ had recorded experience of above 15 years. Most of the dentists $(345,53.4 \%)$ belonged to the west zone followed by north and central zone. The majority $(378,58.5 \%)$ of the respondents were from the private sector, $123(19 \%)$ from the public sector and 145 (22.4\%) were from university clinics. Most of the participants in the study held a BDS degree and a substantial amount held a MDS degree, with a distribution of 285 (44.1\%) and $272(42.1 \%)$ respectively (Table 1).

When the respondents were asked about their previous training or courses of infection control, out of 646 respondents, $392(60.7 \%)$ revealed that they had previous training on infection control. Similarly, 321 (49.7\%) respondents stated that they had training or informative lectures on COVID-19.

\section{Distribution of Level of Knowledge}

Table 2 represents the distribution of the number and frequency of respondents who had selected the correct answer related to knowledge and awareness (Figures 1 and 2). Distribution of overall knowledge among the 646 respondents in the study showed that $62(9.6 \%)$ had a poor level of knowledge, $522(80.8 \%)$ had a fair level of knowledge and $62(9.6 \%)$ had a good level of knowledge (Figure 3).

Distribution of level of knowledge did not differ significantly across the various age groups and the various groups based on the duration of practice $(P$-value $>0.05)$. Distribution
Table I Distribution of Demographic Parameters of the Respondents Participating in the Study

\begin{tabular}{|c|c|}
\hline Parameter & $\begin{array}{l}\text { Distribution of Respondents' } \\
\text { n (\%) }\end{array}$ \\
\hline \multicolumn{2}{|l|}{ Age group } \\
\hline$<30$ years & $230(35.6 \%)$ \\
\hline $30-39$ years & $303(46.9 \%)$ \\
\hline $40-49$ years & $80(12.4 \%)$ \\
\hline$>50$ years & $33(5.1 \%)$ \\
\hline \multicolumn{2}{|l|}{ Gender } \\
\hline Male & $350(54.2 \%)$ \\
\hline Female & $296(45.8)$ \\
\hline \multicolumn{2}{|l|}{ Duration of practice } \\
\hline$<5$ years & $269(41.6 \%)$ \\
\hline $5-15$ years & 277 (42.9\%) \\
\hline$>15$ years & $100(15.5 \%)$ \\
\hline \multicolumn{2}{|l|}{ Zone of practice } \\
\hline Central & 98 (I5.2\%) \\
\hline East & $48(7.4 \%)$ \\
\hline West & 345 (53.4\%) \\
\hline North & $103(15.9 \%)$ \\
\hline South & $52(8.1 \%)$ \\
\hline \multicolumn{2}{|l|}{ Organization } \\
\hline Private sector & $378(58.5 \%)$ \\
\hline Public sector & $123(19.0 \%)$ \\
\hline University Clinics & 145 (22.4\%) \\
\hline \multicolumn{2}{|l|}{ Educational status } \\
\hline BDS & $285(44.1 \%)$ \\
\hline MDS & $272(42.1 \%)$ \\
\hline Post-graduate students & 76 (11.7\%) \\
\hline Doctoral (PhD) & $13(2.0 \%)$ \\
\hline \multicolumn{2}{|l|}{$\begin{array}{l}\text { Training taken (Infection } \\
\text { control) }\end{array}$} \\
\hline Yes & $392(60.7 \%)$ \\
\hline No & $254(39.3 \%)$ \\
\hline \multicolumn{2}{|l|}{ Training taken (COVID-19) } \\
\hline Yes & 321 (49.7\%) \\
\hline No & 325 (50.3\%) \\
\hline
\end{tabular}

of level of knowledge (fair or good) was significantly higher among the female compared to male respondents ( $P$-value $<0.05$ ) (Table 3). Distribution of level of knowledge (fair or good) differs significantly between various zones of practice with highest among the south zone compared to the rest of the zones ( $P$-value $<0.05$ ) (Table 3$)$.

Distribution of the level of knowledge was significantly higher among the group of respondents with a post-graduation degree compared to respondents having only a graduation 
Table 2 Distribution of Level of Knowledge Recorded by Respondents According to Questions

\begin{tabular}{|c|c|c|}
\hline No. & Question & $\begin{array}{l}\text { Correct Answer } \\
\text { Respondents [n (\%)] }\end{array}$ \\
\hline I. & $\begin{array}{l}\text { Among these which is Coronavirus? } \\
\text { a) Common cold, b) Middle East Respiratory Syndrome (MERS), c) Severe Acute Respiratory Syndrome } \\
\text { (SARS), d) COVID-19, e) All, f) Do not know }\end{array}$ & $\begin{array}{l}\text { e) All } \\
292(45.20 \%)\end{array}$ \\
\hline 2. & $\begin{array}{l}\text { Which is more deadly (High mortality)? } \\
\text { a) SARS, b) MERS, c) COVID-19, d) Do not know }\end{array}$ & $\begin{array}{l}\text { b) MERS } \\
65(10 \%)\end{array}$ \\
\hline 3. & $\begin{array}{l}\text { Which is more infectious? } \\
\text { a) SARS, b) MERS, c) COVID-19, d) Do not know }\end{array}$ & $\begin{array}{l}\text { c) COVID-19 } \\
544(84.2 \%)\end{array}$ \\
\hline 4. & $\begin{array}{l}\text { COVID-19 is caused by virus } \\
\text { a) SARS-CoV-2, b) SARS-CoV, c) MERS-CoV, d) Do not know }\end{array}$ & $\begin{array}{l}\text { a) SARS-CoV-2 } \\
546(84.5 \%)\end{array}$ \\
\hline 5. & $\begin{array}{l}\text { What is the incubation period of COVID-19 virus? } \\
\text { a) 2-7 days, b) 2-14 days, c) I-5 days, d) I-2I days, e) Do not know }\end{array}$ & $\begin{array}{l}\text { b) } 2-14 \text { days } \\
587(90.8 \%)\end{array}$ \\
\hline 6. & $\begin{array}{l}\text { What is the overall mortality rate of COVID-19 disease? } \\
\text { a) } 3.2 \% \text {, b) } 6.8 \% \text {, c) } 10.4 \% \text {, d) } 12.6 \% \text {, e) Do not know }\end{array}$ & $\begin{array}{l}\text { b) } 6.8 \% \\
78(12 \%)\end{array}$ \\
\hline 7. & $\begin{array}{l}\text { What is the basic reproduction number (R0-R naught) for COVID-I9? } \\
\text { a) } 2.2 \text {, b) } 5.3, \text { c) } 1.6, \text { d) } 4.2 \text {, e) Do not know }\end{array}$ & $\begin{array}{l}\text { a) } 2.2 \\
69(10.6 \%)\end{array}$ \\
\hline 8. & $\begin{array}{l}\text { What is the laboratory test available to diagnose COVID-19? } \\
\text { a) rRT-PCR, b) ELISA, c) Western Blot, d) DNA hybridization, e) Do not now }\end{array}$ & $\begin{array}{l}\text { a) } \text { rRT-PCR } \\
525(81.2 \%)\end{array}$ \\
\hline
\end{tabular}

degree $(P$-value $<0.05)$. A significantly higher level of knowledge was reported among respondents who had training of infection control compared to those who did not attend any such program in the recent past $(P$-value $<0.05)$. However, a significantly higher level of knowledge was recorded among respondents who had training or informative lectures on COVID-19 ( $P$-value $<0.05)$ (Table 3$)$.

\section{Distribution of Risk Perception and Attitude}

In the present survey, half $(n=329)$ of the total numbers of respondents had the perception that COVID-19 is highly contagious followed by $301(46.6 \%)$ respondents who believed it to be moderately contagious. Of the total respondents, $319(49.4 \%)$ were aware of the fact that $80 \%$ of COVID-19-positive patients present with mild symptoms. The majority of the respondents $(562,87 \%)$ believed that dentists fall in the very high risk exposure category (Table 4).

In response to the question "Which mask should generally be used by Dentists?" almost 50\% $(n=323)$ of the respondents selected Surgical N95 (Medical respirator) as an option, followed by 133 (20.6\%) respondents who opted for a combination of Surgical N95 (Medical respirator) and Standard N95 (Unvalved) as protective gear. Whereas, 91
(14.2\%) respondents believed that only Standard N95 (Unvalved) should be used during the dental procedure. The next question was in relation to the basic requirements to be checked before wearing the N95 mask. Of the total 646 respondents, 231 (35.8\%) believed that only the fit test for proper seal should be checked before use, whereas 178 $(27.6 \%)$ respondents selected all three options (fit test for a proper seal, plus user should have prior training and certain medical condition) (Table 4).

About 299 (46.3\%) respondents decided to use teleconferences to see if the dental treatment could be delayed by prescribing medications to solve the dental problem of a confirmed/suspect COVID-19 patient, followed by 143 $(22.1 \%)$ respondents who selected that they will refer the patient directly to the higher center (Hospital setup). Very few respondents $5(0.8 \%)$ had an opinion that they will examine the patient directly in their dental office to check the severity of the complaint. Most of the respondents (476, $737 \%$ ) were aware of the fact that ultrasonic scaling and use of high-speed headpiece carries the maximum risk of virus transmission while treating a COVID-19-positive patient (Table 4).

Most of the respondents $(508,78.6 \%)$ recorded their agreement when asked that "Are personal protective 


\section{Q. 9 What are the symptoms of COVID-19 infection?}

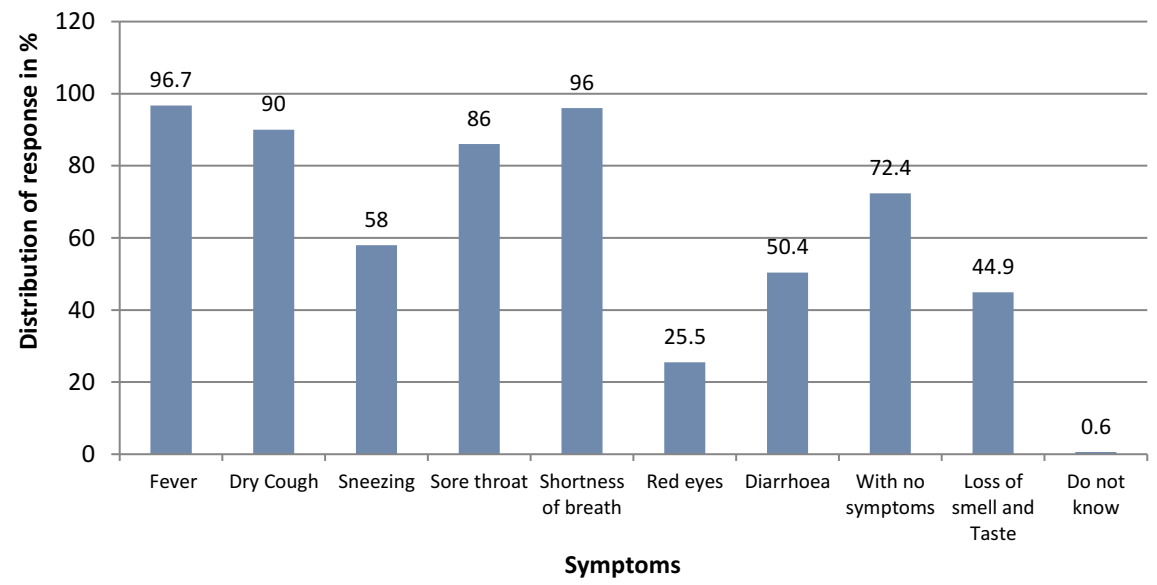

Figure I Response of the participants in relation to Q.9.

\section{Q. 10 How is Covid-19 transmitted?}

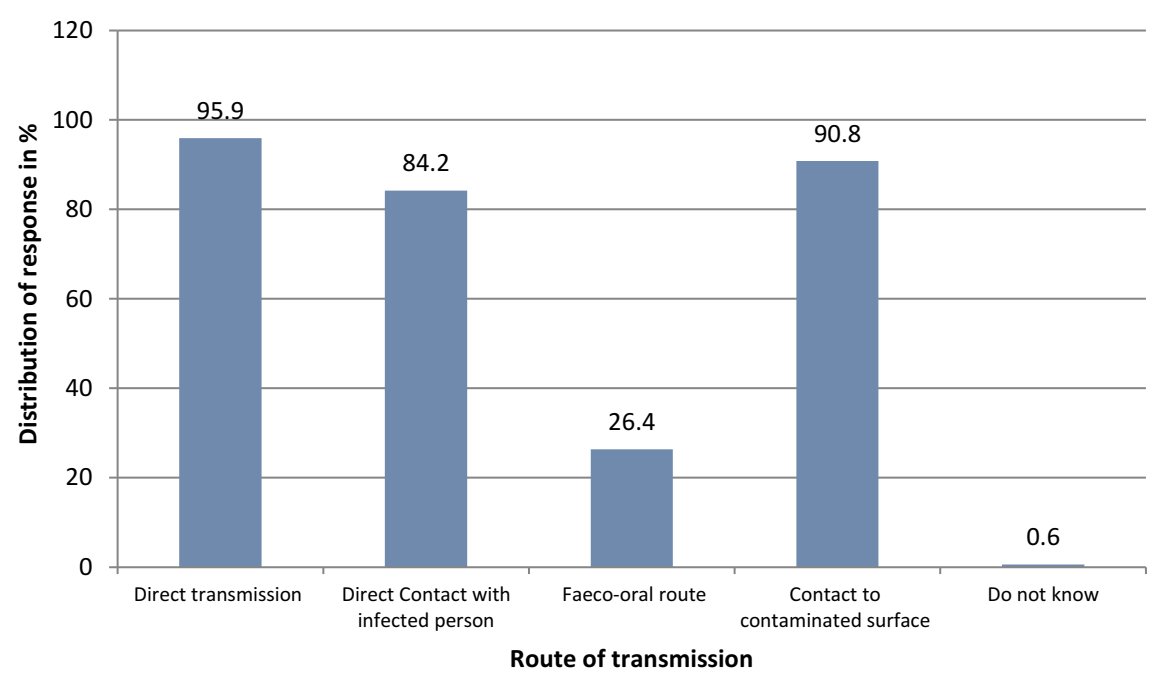

Figure 2 Response of the participants in relation to Q.10.

\section{Distribution of level of knowledge}

a Poor [<40\%] $\square$ Fair [40\%-70\%] $\square \operatorname{Good}[>70 \%]$

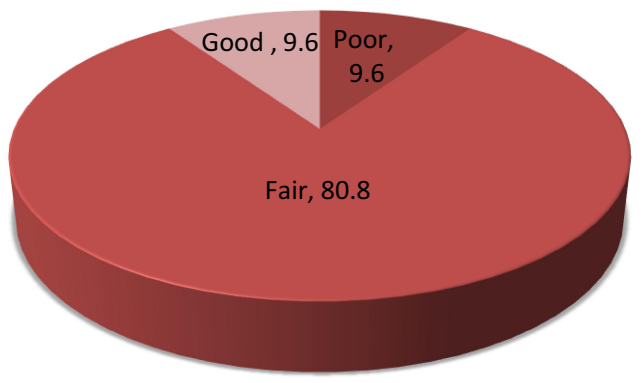

Figure 3 Distribution of level of knowledge among the respondents participated in the study. 
Table 3 Distribution of Level of Knowledge According to Various Demographic Characteristics of Respondents who Participated in the Study

\begin{tabular}{|c|c|c|c|c|c|c|c|c|c|}
\hline \multirow[t]{3}{*}{ Characteristics } & \multicolumn{9}{|c|}{ Level of Knowledge } \\
\hline & \multicolumn{2}{|c|}{ Poor $(n=62)$} & \multicolumn{2}{|c|}{ Fair $(n=522)$} & \multicolumn{2}{|c|}{ Good $(n=62)$} & \multicolumn{2}{|c|}{ Total $(n=646)$} & \multirow[t]{2}{*}{$P$-value } \\
\hline & $\mathbf{n}$ & $\%$ & $\mathbf{n}$ & $\%$ & $\mathbf{n}$ & $\%$ & $\mathbf{n}$ & $\%$ & \\
\hline \multicolumn{10}{|l|}{ Age group } \\
\hline$<30$ years & 18 & 7.8 & 193 & 83.9 & 19 & 8.3 & 230 & 100.0 & \\
\hline $30-39$ years & 34 & 11.2 & 233 & 76.9 & 36 & 11.9 & 303 & 100.0 & $0.348^{\mathrm{NS}}$ \\
\hline $40-49$ years & 7 & 8.8 & 67 & 83.8 & 6 & 7.5 & 80 & 100.0 & \\
\hline$>50$ years & 3 & 9.1 & 29 & 87.9 & I & 3.0 & 33 & 100.0 & \\
\hline \multicolumn{10}{|l|}{ Gender } \\
\hline Male & 45 & 12.9 & 267 & 76.3 & 38 & 10.9 & 350 & 100.0 & $0.003 * *$ \\
\hline Female & 17 & 5.7 & 255 & 86.1 & 24 & 8.1 & 296 & 100.0 & \\
\hline \multicolumn{10}{|l|}{ Duration of practice } \\
\hline$<5$ years & 23 & 8.6 & 225 & 83.6 & 21 & 7.8 & 269 & 100.0 & \\
\hline $5-15$ years & 29 & 10.5 & 219 & 79.1 & 29 & 10.5 & 277 & 100.0 & $0.603^{\mathrm{NS}}$ \\
\hline$>15$ years & 10 & 10.0 & 78 & 78.0 & 12 & 12.0 & 100 & 100.0 & \\
\hline \multicolumn{10}{|l|}{ Zone of practice } \\
\hline Central & 2 & 2.0 & 84 & 85.7 & 12 & 12.2 & 98 & 100.0 & \\
\hline East & 5 & 10.4 & 41 & 85.4 & 2 & 4.2 & 48 & 100.0 & \\
\hline West & 37 & 10.7 & 278 & 80.6 & 30 & 8.7 & 345 & 100.0 & $0.001 * * *$ \\
\hline North & 14 & 13.6 & 84 & 81.6 & 5 & 4.9 & 103 & 100.0 & \\
\hline South & 4 & 7.7 & 35 & 67.3 & 13 & 25.0 & 52 & 100.0 & \\
\hline \multicolumn{10}{|l|}{ Organization } \\
\hline Private sector & 39 & 10.3 & 314 & 83.1 & 25 & 6.6 & 378 & 100.0 & \\
\hline Public sector & 10 & 9.3 & 86 & 72.2 & 27 & 18.5 & 123 & 100.0 & $0.00 I^{* * *}$ \\
\hline University Clinics & 13 & 9.0 & 122 & 84.1 & 10 & 6.9 & 145 & 100.0 & \\
\hline \multicolumn{10}{|l|}{ Educational status } \\
\hline BDS & 29 & 10.2 & 242 & 84.9 & 14 & 4.9 & 285 & 100.0 & \\
\hline MDS & 0 & 0.0 & 67 & 88.2 & 9 & 11.8 & 76 & 100.0 & $0.001 * * *$ \\
\hline Post-graduate students & 32 & 11.8 & 202 & 74.3 & 38 & 14.0 & 272 & 100.0 & \\
\hline $\mathrm{PhD}$ & I & 7.7 & II & 84.6 & 1 & 7.7 & 13 & 100.0 & \\
\hline \multicolumn{10}{|c|}{ Training taken (Infection control) } \\
\hline Yes & 2 & 6.1 & 323 & 82.4 & 45 & 11.5 & 392 & 100.0 & $0.00 I^{* * *}$ \\
\hline No & 38 & 15.0 & 199 & 78.3 & 17 & 6.7 & 254 & 100.0 & \\
\hline \multicolumn{10}{|c|}{ Training taken (COVID-19) } \\
\hline Yes & 18 & 5.6 & 268 & 83.5 & 35 & 10.9 & 321 & 100.0 & $0.002 * *$ \\
\hline No & 44 & 13.5 & 254 & 78.2 & 27 & 8.3 & 325 & 100.0 & \\
\hline
\end{tabular}

Notes: $P$-value for Chi-square test. $P$-value $<0.05$ is considered to be statistically significant. $* * P$-value $<0.01$, $* * * P$-value $<0.00$ I, NS-statistically non-significant. Higher mean score indicates higher level of knowledge and vice-versa.

equipment useful in protecting from confirmed/suspected COVID-19 patients? Very few respondents $(76,11.8 \%)$ recorded disagreement with the above statement. Of the 646 respondents, $270(41.8 \%)$ recorded a positive attitude towards providing emergency dental treatment to COVID- 19-positive patients, whereas 264 (20.9\%) refrained from providing emergency dental treatment. Most of the respondents $(536,83 \%)$ showed a positive attitude towards providing dental treatment for the previous COVID-19positive patients (Table 4). 
Table 4 Distribution of Risk Perception and Attitude of the Respondents who Participated in the Study

\begin{tabular}{|c|c|c|c|}
\hline Risk Perception & Response & $\mathbf{n}$ & $\%$ \\
\hline \multirow[t]{3}{*}{ Perception about COVID-19 } & Highly contagious & 329 & 50.9 \\
\hline & Moderately contagious & 301 & 46.6 \\
\hline & Non contagious & 16 & 2.5 \\
\hline \multirow[t]{4}{*}{$\%$ COVID-19 +ve patients shows mild symptoms } & $80 \%$ & 319 & 49.4 \\
\hline & $60 \%$ & 165 & 25.5 \\
\hline & $40 \%$ & 98 & 15.2 \\
\hline & Do not know & 64 & 9.9 \\
\hline \multirow[t]{3}{*}{ Under which category do dentists fall in the risk of exposure? } & Very high exposure risk job & 562 & 87.0 \\
\hline & High exposure risk job & 80 & 12.4 \\
\hline & Low exposure risk job & 4 & 0.6 \\
\hline \multirow[t]{7}{*}{ Which mask should generally be used by dentists? } & Al & 323 & 50.0 \\
\hline & $A 1+A 2$ & 133 & 20.6 \\
\hline & $\mathrm{A} 2$ & 92 & 14.2 \\
\hline & $A 1+A 2=A 3$ & 34 & 5.3 \\
\hline & $\mathrm{Al}+\mathrm{A} 3$ & 24 & 3.7 \\
\hline & Other & 36 & 5.6 \\
\hline & Do not know & 4 & 0.6 \\
\hline \multirow[t]{7}{*}{ Which of the following needs to be checked before wearing N95? } & $\mathrm{BI}$ & 231 & 35.8 \\
\hline & $\mathrm{B} 1+\mathrm{B} 2+\mathrm{B} 3$ & 178 & 27.6 \\
\hline & $\mathrm{B} 1+\mathrm{B} 2$ & 104 & 16.1 \\
\hline & B2 & 37 & 5.7 \\
\hline & $\mathrm{BI}+\mathrm{B} 3$ & 29 & 4.5 \\
\hline & Other non-relevant combination & 26 & 4.0 \\
\hline & Do not know & 41 & 6.3 \\
\hline \multirow{4}{*}{$\begin{array}{l}\text { What would you do for a dental problem of a confirmed/suspect } \\
\text { COVID-19 patient? }\end{array}$} & $\mathrm{Cl}$ & 299 & 46.3 \\
\hline & $\mathrm{Cl}+\mathrm{C} 2$ & 199 & 30.8 \\
\hline & $\mathrm{C} 2$ & 143 & 22.1 \\
\hline & $\mathrm{C} 3$ & 5 & 0.8 \\
\hline \multirow{8}{*}{$\begin{array}{l}\text { What dental procedures carry the maximum risk of virus } \\
\text { transmission while treating a COVID-19-positive patient? }\end{array}$} & $\mathrm{DI}+\mathrm{D} 2$ & 476 & 73.7 \\
\hline & D2 & 32 & 5.0 \\
\hline & $\mathrm{DI}+\mathrm{D} 2+\mathrm{D} 3$ & 57 & 8.8 \\
\hline & $\mathrm{DI}+\mathrm{D} 2+\mathrm{D} 4$ & 26 & 4.0 \\
\hline & DI & 20 & 3.1 \\
\hline & $\mathrm{DI}+\mathrm{D} 2+\mathrm{D} 5$ & 25 & 3.9 \\
\hline & Other non-relevant combination & 8 & 1.2 \\
\hline & Do not know & 2 & 0.3 \\
\hline \multirow{3}{*}{$\begin{array}{l}\text { Are the personal protective equipments useful in protecting from } \\
\text { confirmed/suspected COVID-19 patients? }\end{array}$} & Agree & 508 & 78.6 \\
\hline & Disagree & 76 & 11.8 \\
\hline & Do not know & 62 & 9.6 \\
\hline \multirow{3}{*}{$\begin{array}{l}\text { Will you provide emergency dental treatment to a COVID-19- } \\
\text { positive patient? }\end{array}$} & Yes & 270 & 41.8 \\
\hline & No & 264 & 40.9 \\
\hline & Do not know & 112 & 17.3 \\
\hline \multirow{3}{*}{$\begin{array}{l}\text { Will you provide dental treatment to a previous COVID-19- } \\
\text { positive patient? }\end{array}$} & Yes & 536 & 83.0 \\
\hline & No & 81 & 12.4 \\
\hline & Do not Know & 29 & 4.6 \\
\hline
\end{tabular}

(Continued) 
Table 4 (Continued).

\begin{tabular}{|l|l|l|l|l|}
\hline \multicolumn{2}{|l|}{ Risk Perception } & Response & $\mathbf{n}$ & $\%$ \\
\hline \multicolumn{2}{|l|}{ Key elaboration for Table 4 } & BI & Fit test for proper seal \\
AI & Surgical N95 (Medical respirator) & Standard N95 (Unvalved) & B2 & User should have prior training \\
A3 & Surgical Mask & B3 & Certain medical condition \\
C1 & Use teleconference and if the dental treatment can be & DI & Ultrasonic scaling \\
& delayed give advice about pharmaceuticals & D2 & Use of high speed headpiece \\
C2 & Refer the patient directly to the higher center & D3 & Dental procedures under rubber \\
& & & dam \\
C3 & Examine the patient directly in your dental office to check & D4 & Crown cementation \\
& the severity of the dental condition & D5 & Use of lasers \\
\hline
\end{tabular}

\section{Distribution of Preparedness}

Distribution of Level of Preparedness According to Training Taken (Infection Control)

Distribution of level of preparedness in terms of training to be provided to the staff, precautions to be taken during treatment and preparation of the body to prevent COVID-19 did not differ significantly among respondents with and without training of infection control ( $P$-value $>0.05$ ). However, distribution of level of preparedness in terms of contacting the appropriate organization if they had an unprotected exposure to a known or suspected COVID-19 patient and if having signs or symptoms of COVID-19 infection differed significantly between the groups $(P$-value $<0.05)$ (Table 5 ).

\section{Distribution of Level of Preparedness According to Training Taken (COVID-19)}

A significantly higher level of preparedness in all aspects was recorded among respondents in the group who received training about COVID-19 compared to the group who never had training related to the COVID-19 infection.

\section{Discussion}

COVID-19 has emerged as a major healthcare concern around the world. Presently in India, private and public dental clinics are attending only emergency cases. However, practicing dentistry during such a pandemic is a first time experience for most dentists. The possible transmission routes in the dental clinic include direct contact by face-to-face communication, exposure to saliva, blood and other body fluids. Indirect contact can be due to contaminated instruments and the clinic environment. ${ }^{17}$ Considering the highly infectious nature of COVID-19, adequate training is required to carry out safe practice to prevent the spread to the working staff. These measures include wearing PPE, sterilized gloves, and respirators. ${ }^{18}$ The regulatory bodies are providing online training for diseases and their precautionary measures. ${ }^{19}$ The present survey was therefore undertaken among dentists in India to assess the knowledge and preparedness about COVID-19.

The majority $(80.8 \%)$ of the respondents had a fair level $(40-70 \%)$ of knowledge, which was significantly more among female respondents and those with postgraduation studies. This percentage is less when compared to the study conducted by Kamate et $\mathrm{al}^{19}$ in which $92.7 \%$ had a fair level of knowledge which could be due to the fact that it was a multinational study including developed countries like America and Australia. ${ }^{19}$ However this was in contrast to a study by Putrino et $\mathrm{al}^{20}$ in which males were more aware of the disease as compared to female participants. ${ }^{20}$ It was similar to a study by Quadri et $\mathrm{al}^{21}$ in which specialists had higher knowledge compared to auxiliaries and interns. ${ }^{21}$ Distribution of level of knowledge did not differ significantly across various age groups and duration of practice but was highest among those in the south zone. Most of the respondents were familiar with the wide variety of the symptoms that the patient can present at the clinic which is of utmost importance for the early diagnosis of the suspected positive patients. On the other hand, the asymptomatic carriers can pose the real problem as they have no or very mild symptoms which can be overlapping with other viral infections like common cold and flu. This requires that the dentists should consider each patient in the clinic to be a COVID-19 positive and take all the necessary precautions as such patients could sometimes be misjudged as normal patients (without COVID19). Regarding the mode of transmission, nearly all 
Table 5 Distribution of Level of Preparedness According to Training Taken (Infection Control/COVID-I9) Among the Respondents who Participated in the Study

\begin{tabular}{|c|c|c|c|c|c|c|c|c|c|c|c|}
\hline \multirow[b]{3}{*}{ Level of Preparedness } & \multirow[b]{3}{*}{ Response } & \multicolumn{4}{|c|}{$\begin{array}{l}\text { Training Taken } \\
\text { (Infection Control) }\end{array}$} & \multirow{3}{*}{ P-value } & \multicolumn{4}{|c|}{$\begin{array}{l}\text { Training Taken } \\
\text { (COVID-19) }\end{array}$} & \multirow{3}{*}{ P-value } \\
\hline & & \multicolumn{2}{|c|}{$\begin{array}{l}\text { No } \\
(n=254)\end{array}$} & \multicolumn{2}{|c|}{$\begin{array}{l}\text { Yes } \\
(n=392)\end{array}$} & & \multicolumn{2}{|c|}{$\begin{array}{l}\text { No } \\
(n=325)\end{array}$} & \multicolumn{2}{|c|}{$\begin{array}{l}\text { Yes } \\
(n=321)\end{array}$} & \\
\hline & & $\mathbf{n}$ & $\%$ & $\mathbf{n}$ & $\%$ & & $\mathbf{n}$ & $\%$ & $\mathbf{n}$ & $\%$ & \\
\hline $\begin{array}{l}\text { Dentist should provide adequate training to their } \\
\text { staff to promote many levels of screening and } \\
\text { preventive measures. }\end{array}$ & $\begin{array}{l}\text { Agree } \\
\text { Disagree } \\
\text { Do not } \\
\text { know }\end{array}$ & $\begin{array}{l}248 \\
2 \\
4\end{array}$ & $\begin{array}{l}97.6 \\
0.8 \\
1.6\end{array}$ & $\begin{array}{l}390 \\
0 \\
2\end{array}$ & $\begin{array}{l}99.5 \\
0.0 \\
0.5\end{array}$ & $0.081^{N S}$ & $\begin{array}{l}315 \\
3 \\
7\end{array}$ & $\begin{array}{l}97.0 \\
1.0 \\
2.0\end{array}$ & $\begin{array}{l}321 \\
0 \\
0\end{array}$ & $\begin{array}{l}100 \\
0.0 \\
0.0\end{array}$ & $0.018^{*}$ \\
\hline $\begin{array}{l}\text { What precautions should the dental practitioners } \\
\text { take when treating COVID-19-positive patients? }\end{array}$ & $\begin{array}{l}\text { EI } \\
\text { E2 } \\
\text { E3 } \\
\text { E4 } \\
\text { E5 } \\
\text { E6 }\end{array}$ & $\begin{array}{l}190 \\
15 \\
14 \\
17 \\
6 \\
12\end{array}$ & $\begin{array}{l}74.8 \\
5.9 \\
5.5 \\
6.7 \\
2.4 \\
4.7\end{array}$ & $\begin{array}{l}307 \\
18 \\
6 \\
24 \\
9 \\
28\end{array}$ & $\begin{array}{l}78.3 \\
4.6 \\
1.5 \\
6.1 \\
2.3 \\
7.1\end{array}$ & $0.070^{\mathrm{NS}}$ & $\begin{array}{l}230 \\
24 \\
15 \\
22 \\
16 \\
18\end{array}$ & $\begin{array}{l}71.2 \\
7.4 \\
2.8 \\
6.8 \\
1.8 \\
5.5\end{array}$ & $\begin{array}{l}260 \\
8 \\
9 \\
15 \\
9 \\
19\end{array}$ & $\begin{array}{l}79.7 \\
2.4 \\
2.8 \\
5.3 \\
2.8 \\
6.2\end{array}$ & $0.026 *$ \\
\hline $\begin{array}{l}\text { How to prepare your body to prevent and avoid } \\
\text { getting COVID-19 infection? }\end{array}$ & $\begin{array}{l}\text { FI } \\
\text { F2 } \\
\text { F3 } \\
\text { F4 } \\
\text { F5 } \\
\text { F6 }\end{array}$ & $\begin{array}{l}191 \\
28 \\
14 \\
11 \\
4 \\
6\end{array}$ & $\begin{array}{l}75.2 \\
11.0 \\
5.5 \\
4.3 \\
1.6 \\
2.4\end{array}$ & $\begin{array}{l}306 \\
39 \\
27 \\
5 \\
7 \\
8\end{array}$ & $\begin{array}{l}78.1 \\
9.9 \\
6.9 \\
1.3 \\
1.8 \\
2.0\end{array}$ & $0.242^{\mathrm{NS}}$ & $\begin{array}{l}250 \\
36 \\
17 \\
14 \\
0 \\
8\end{array}$ & $\begin{array}{l}76.9 \\
11.1 \\
5.2 \\
4.3 \\
0.0 \\
2.8\end{array}$ & $\begin{array}{l}247 \\
31 \\
24 \\
2 \\
11 \\
6\end{array}$ & $\begin{array}{l}76.9 \\
9.7 \\
7.5 \\
0.6 \\
3.4 \\
1.9\end{array}$ & $0.001 * * *$ \\
\hline $\begin{array}{l}\text { Do you know whom to contact if you have an } \\
\text { unprotected exposure to a known or suspected } \\
\text { COVID-19 patient? }\end{array}$ & $\begin{array}{l}\text { Yes } \\
\text { No }\end{array}$ & $\begin{array}{l}206 \\
48\end{array}$ & $\begin{array}{l}81.1 \\
18.9\end{array}$ & $\begin{array}{l}362 \\
30\end{array}$ & $\begin{array}{l}92.3 \\
7.7\end{array}$ & $0.001 * * *$ & $\begin{array}{l}270 \\
55\end{array}$ & $\begin{array}{l}83.1 \\
16.9\end{array}$ & $\begin{array}{l}298 \\
23\end{array}$ & $\begin{array}{l}92.8 \\
7.2\end{array}$ & $0.001 * * *$ \\
\hline $\begin{array}{l}\text { Do you know what to do if you have signs or } \\
\text { symptoms suspected of COVID-19 infection? }\end{array}$ & $\begin{array}{l}\text { Yes } \\
\text { No }\end{array}$ & $\begin{array}{l}234 \\
20\end{array}$ & $\begin{array}{l}92.1 \\
7.9\end{array}$ & $\begin{array}{l}387 \\
5\end{array}$ & $\begin{array}{l}98.7 \\
1.3\end{array}$ & $0.001 * * *$ & $\begin{array}{l}305 \\
20\end{array}$ & $\begin{array}{l}93.8 \\
6.2\end{array}$ & $\begin{array}{l}316 \\
5\end{array}$ & $\begin{array}{l}98.4 \\
1.6\end{array}$ & $0.002^{* *}$ \\
\hline \multicolumn{12}{|l|}{ Key elaboration for Table 5} \\
\hline EI & \multicolumn{11}{|c|}{$\begin{array}{l}\text { AllRs should be reserved for patients, Air from these rooms should be exttacted directly by } \\
\text { high-efficiency particulate air (HEPA) filter, Pre-procedural mouth rinse with } 0.2 \% \text { povidone- } \\
\text { iodine, Extra-oral imaging should be preferred to intra-oral imaging }\end{array}$} \\
\hline E2 & \multicolumn{11}{|c|}{$\begin{array}{l}\text { AllRs should be reserved for patients, Air from these rooms should be extracted directly by } \\
\text { high-efficiency particulate air (HEPA) filter, Pre-procedural mouth rinse with } 0.2 \% \text { povidone- } \\
\text { iodine, Rubber dam should be used to minimize splatter generation }\end{array}$} \\
\hline E3 & \multicolumn{11}{|c|}{$\begin{array}{l}\text { AllRs should be reserved for patients, Air from these rooms should be exhausted directly by } \\
\text { high-efficiency particulate air (HEPA) filter, Pre-procedural mouth rinse with } 0.2 \% \text { povidone- } \\
\text { iodine, Extra-oral imaging should be preferred, Rubber dam should be used. Minimize the } \\
\text { use of ultrasonic instruments, high-speed headpieces, and 3-way syringes. }\end{array}$} \\
\hline E4 & \multicolumn{11}{|c|}{ AllRs should be reserved for patients } \\
\hline E5 & \multicolumn{11}{|c|}{$\begin{array}{l}\text { AllRs should be reserved for patients, Air from these rooms should be extracted directly by } \\
\text { high-efficiency particulate air (HEPA) filter. }\end{array}$} \\
\hline E6 & \multicolumn{11}{|l|}{ Other } \\
\hline
\end{tabular}

(Continued) 
Table 5 (Continued).

\begin{tabular}{|c|c|c|c|c|c|c|c|c|c|c|c|}
\hline \multirow[b]{3}{*}{ Level of Preparedness } & \multirow[b]{3}{*}{ Response } & \multicolumn{4}{|c|}{$\begin{array}{l}\text { Training Taken } \\
\text { (Infection Control) }\end{array}$} & \multirow{3}{*}{ P-value } & \multicolumn{4}{|c|}{$\begin{array}{l}\text { Training Taken } \\
\text { (COVID-19) }\end{array}$} & \multirow{3}{*}{ P-value } \\
\hline & & \multicolumn{2}{|c|}{$\begin{array}{l}\text { No } \\
(n=254)\end{array}$} & \multicolumn{2}{|c|}{$\begin{array}{l}\text { Yes } \\
(n=392)\end{array}$} & & \multicolumn{2}{|c|}{$\begin{array}{l}\text { No } \\
(n=325)\end{array}$} & \multicolumn{2}{|c|}{$\begin{array}{l}\text { Yes } \\
(n=321)\end{array}$} & \\
\hline & & n & $\%$ & $\mathbf{n}$ & $\%$ & & $\mathbf{n}$ & $\%$ & $\mathbf{n}$ & $\%$ & \\
\hline $\mathrm{FI}$ & \multicolumn{11}{|c|}{$\begin{array}{l}\text { Take proper rest and sleep, Daily intake of vitamin } C \text { in the form of citrus fruits, Drinking } \\
\text { warm water and doing gargles with warm water mixed with povidone-iodine, salt etc, } \\
\text { Exercise routinely to keep the body fit, Avoiding panic and psychological negative effects o } \\
\text { the disease }\end{array}$} \\
\hline $\mathrm{F} 2$ & \multicolumn{11}{|c|}{$\begin{array}{l}\text { Daily intake of vitamin } C \text { in the form of citrus fruits, Drinking warm water and doing gargles } \\
\text { with warm water mixed with povidone-iodine, salt etc, Avoiding panic and psychological } \\
\text { negative effects of the disease }\end{array}$} \\
\hline F3 & \multicolumn{11}{|c|}{$\begin{array}{l}\text { Drinking warm water and doing gargles with warm water mixed with povidone-iodine, salt } \\
\text { etc }\end{array}$} \\
\hline F4 & \multicolumn{11}{|c|}{$\begin{array}{l}\text { Take proper rest and sleep, Drinking warm water and doing gargles with warm water mixed } \\
\text { with povidone-iodine, salt etc, Exercise routinely to keep the body fit, Avoiding panic and } \\
\text { psychological negative effects of the disease }\end{array}$} \\
\hline F5 & \multicolumn{11}{|c|}{ Take proper rest and sleep } \\
\hline F6 & \multicolumn{11}{|l|}{ Other } \\
\hline
\end{tabular}

Notes: $P$-value for Chi-square test. $P$-value $<0.05$ is considered to be statistically significant. $* P$-value $<0.05, * * P$-value $<0.01, * * * P$-value $<0.001, N S$-statistically nonsignificant. Higher mean score indicates higher level of knowledge and vice-versa.

Abbreviation: AllRs, airborne infection isolation rooms

respondents had a fair knowledge which means the dentist knows how to prevent the community spread of the current pandemic. This is very crucial especially to save the lives of the vulnerable patients who are more than 60 years old and suffering from pre-existing chronic illnesses. Regarding the level of training, the distribution of knowledge was significantly more among those having some training in infection control or those who had followed an informative lecture or training session on COVID-19. It also underlies the importance of keeping updated as the virus is continuously evolving and there might be changes in the protocols as more scientific evidence is gained.

Only $45 \%$ of the respondents knew about all the different types of coronavirus and only $10 \%$ knew that MERS has the highest mortality rate among all types of coronavirus. On a positive note $84.2 \%$ of them were conscious that COVID-19 is more infectious than the others which states the inquisitiveness that has been created by the new virus. Despite this, $84.5 \%$ of the respondents knew that COVID-19 is caused by SARS-CoV-2 but only $6.6 \%$ had an idea about the basic reproduction number (R0-R naught) of the virus which is reported as 2.2. This number can be defined as the average number of secondary cases attributable to infection by an index case after that case is introduced into a susceptible population. This number might increase with more well-defined studies which means the infectivity of the virus might be more than what we currently think and all the healthcare professionals need to have the updated information. Similarly, $90.8 \%$ of respondents knew about the incubation period of the virus (2-14 days) yet only $12 \%$ perceived the overall mortality rate by it. This may be partly due to the previous studies which stated a mortality rate of $3.4 \%{ }^{22,23}$ But according to the currently available data, the mortality rate is as high as $6.8 \%{ }^{24} \mathrm{~A}$ greater number $(81.2 \%)$ of the participants agreed that the rRT-PCR laboratory test can help in the diagnosis of the suspected and asymptomatic cases. This real-time RT-PCR test works by the qualitative revelation of the nucleic acid of the SARS-CoV-2 in upper and lower respiratory specimens. ${ }^{25}$ Though a positive result is suggestive of progressive infection with SARS-CoV-2 but it does not rule out other bacterial and viral infections. Also, the 
negative results cannot rule out the absence of COVID-19, so proper decisions should be made following the patient's symptoms, travel history, and geographical location.

Nearly $50 \%$ of the respondents perceived COVID-19 as very dangerous. This can be correlated to the fact that nearly the same number of participants feel that almost $80 \%$ of the patients can present with mild or no symptoms. ${ }^{4,26}$ Such patients pose the highest risk as these almost asymptomatic ones can not only act as carriers of infection to others but also can be the reservoirs of the disease causing reinfection unintentionally. This is in accordance with the study by De Stefani et $\mathrm{al}^{27}$ where the dentists recognized COVID-19 to be a highly dangerous viral infection. ${ }^{27}$ This made $87 \%$ of the dentists believe that their job falls under very high risk category of exposure. It is in accordance with a study by Cagetti et $\mathrm{al}^{28}$ where the majority of the respondents believe that the risk of infection transmission is high in the dental practice. ${ }^{28}$ Treating such patients can act like starting a chain reaction of spreading the infection to subsequent patients as the containment of the virus has not yet been fully understood. ${ }^{29}$ Nearly $85 \%$ of the dentists were well versed with the type of mask and were ready to use the N95 mask especially when dealing with COVID-19 patients. A surgical N95 respirator also called as a medical respirator is to be used by healthcare professionals that specifically need protection from airborne and fluid splashes. If there is a shortage of surgical N95 respirators then standard N95 respirators can be used with a face shield. For all other healthcare professionals, a standard N95 respirator can be used. Though most of the respondents agreed with wearing a N95 respirator, 35.8\% felt that only a fit test should be done to check the seal and only $27.6 \%$ knew that they should be medically evaluated and properly trained to make sure that it feels comfortable donning the respirator and also know how to carry on a user seal check. This signifies the importance of the following the complete protocol when using N95 respirators.

Nearly all the dentists thought that it is not a good idea to examine the patient directly in the dental office as about $46.3 \%$ respondents agreed for teleconferencing with the patients and delaying any treatment if the problem can be resolved by advising medications. Additionally, 30.8\% also felt that any patient requiring a visit to the dental office for treating the dental problem that cannot be managed with medications should be referred directly to better equipped higher centers which can facilitate such cases in a better way. The majority $(73.7 \%)$ of the dentists were aware that the dental procedures involving the use of ultrasonic scalers and high-speed handpieces carry the maximum risk of transmission of the virus along with aerosol particles. The virus can sustain on inanimate surfaces for almost 3 days making rigorous disinfection protocol a must for every dental office. $^{30}$ The majority $(78.6 \%)$ of the dentists agreed that wearing personal protective equipment like gloves, mask and goggles can be effective in preventing transmission of COVID-19 which was in accordance with the study by Khader et $\mathrm{al}^{31}$ where $92.9 \%$ of respondents felt the same. Nearly $42 \%$ of the respondents were willing to provide emergency treatment to patients having COVID-19. It is in contrast to the study by Khader et al in which $82.6 \%$ of the dentists preferred to avoid treating a suspected COVID-19 patient as the majority of these patients will have no or mild symptoms during the incubation periods but can be very effective in transmitting the disease. ${ }^{31}$ There are some dental emergencies especially Orofacial fractures and space infections which require surgical intervention and cannot be treated alone by medications. Treating COVID-19 patients requires the dentist to follow and keep updated with the recent guidelines mentioned by the Centers for Disease Control and Prevention (CDC) and World Health Organization (WHO) very precisely. ${ }^{32-35}$ On the contrary, $83 \%$ of the respondents of the current study were ready to treat the patients who had contracted the disease previously but are disease free now.

To evaluate the preparedness in the current study, most of the dentists agreed to provide adequate training to their staff. According to the recommendation by the Occupational Safety and Health Administration (OSHA), a dental professional should keep their staff up to date and educated consistently to keep a healthy and protected dental office. Most of the dentists in the current survey were aware of the precautionary measures to be taken while treating COVID-19 positive patients, irrespective of their training status. These results are in agreement with the results published in the study conducted by Ahmed et al. ${ }^{14}$ The pre-procedural rinsing should be done with $0.2 \%$ povidone-iodine or $0.5-1 \%$ hydrogen peroxide as an antimicrobial mouth rinse can reduce the load of virus in the oral cavity. ${ }^{17,36,37}$ Airborne Infection Isolation Rooms (AIIRs) should be reserved for patients. ${ }^{38}$ Air from these rooms should be extracted directly to the outside or be filtered through a high-efficiency particulate air (HEPA) filter. Often the disposable devices should be used and extra-oral imaging should be preferred to intraoral imaging to avoid stimulation of saliva and cough. 
Rubber dam use should be maximized and the use of ultrasonic instruments, high-speed handpieces, and 3-way syringes should be reduced to avoid aerosol generation. Cleaning and disinfection of the surfaces should be done at least once daily first with regular soap or detergent and then with $0.1 \%$ sodium hypochlorite (ie, equivalent to 1000 ppm).

The majority of the respondents have recorded good awareness about the preparedness of the body to prevent getting COVID-19 infection. The obvious reason for this high level of awareness is the continuous circulation of messages from the health department and educational videos and posts on social media during the current pandemic. About $80-90 \%$ of the respondents were aware of whom to contact if they have unprotected exposure to a known or suspected COVID-19 patient. In the current study higher awareness level was recorded in the respondents who had past training about infection control and COVID-19. This finding was in contrast to the study conducted by Khader et al, which revealed that only half of the dentists $(58.2 \%)$ were aware of whom to contact in such a situation. ${ }^{31}$ The Centers for Disease Control and Prevention (CDC) has divided the exposures into high risk, medium risk and low risk depending upon the type of contact with COVID-19 patients. Almost all the respondents who had past training about the infection control and COVID-19 were aware about their plan of action if they develop signs or symptoms suspected of COVID-19 infection. In contrast, $75.8 \%$ of Jordanian dentists reported that they knew what to do if they developed signs or symptoms of a suspected COVID-19 infection. $^{31}$

\section{Limitations}

Despite implementing all the possible measures to reduce bias, the study was still prone to some limitations. The major limitation was short time duration for data collection assuming the rapid effect this pandemic is currently having on dental health professionals, which could have resulted in a smaller than expected sample. The data collection was done only on social media so it could have resulted in the exclusion of the practitioners who were not using social media or those who were busy taking care of personal affairs. Some states or regions across the country were more affected than others which may influence the administration and healthcare preventive measures implemented by a particular region that could also influence the result of a study. Therefore, the findings of the current survey should be interpreted cautiously and should not be generalized. Based on the available study design (cross-sectional) we are not in a position to conclude a cause-effect association.

\section{Conclusion}

In the present study, Indian dentists have revealed satisfactory knowledge about the COVID-19 etiology, symptoms, diagnosis and mode of transmission as the majority of them had a fair level of knowledge with significantly higher knowledge among female respondents and those with post-graduation studies. The respondents have recorded a good judgement about the risk perception as they know they fall in the very high risk exposure category and showed a positive attitude towards performing dental treatment in the current COVID-19 crisis. Despite having a satisfactory level of knowledge and risk perception, dental practitioners around the country were in a state of anxiety and stress about working in their respective fields. The dentists were also recommended to pursue the CDC and WHO guidelines in their clinics, so as to fight the pandemic in a more sophisticated way. Finally, all the dental professionals should attend the COVID-19 training program to improve their knowledge and to be well aware of the best practices and recommended approaches for infection control.

\section{Data Sharing Statement}

The data used to support the findings of this study are available from the corresponding author upon request.

\section{Ethical Approval}

All procedures performed in the study were in accordance with the ethical standards of the institutional research committee and with the 1964 Helsinki declaration and its later amendments. The Research Ethic's Committee, Indian Dental Association (Bathinda) approved the research with the approval number: 2020-3645

\section{Author Contributions}

All authors made a significant contribution to the work reported, whether that is in the conception, study design, execution, acquisition of data, analysis and interpretation; took part in drafting, revising or critically reviewing the article; gave final approval of the version to be published; have agreed on the journal to which the article has been 
submitted; and agree to be accountable for all aspects of the work.

\section{Funding}

The authors received no financial support for the research, authorship, and/or publication of this article.

\section{Disclosure}

The authors report no conflicts of interest in this work.

\section{References}

1. Huang X, Wei F, Hu L, Wen L, Chen K. Epidemiology and clinical characteristics of COVID-19. Arch Iran Med. 2020;23(5):268-271. doi:10.34172/aim.2020.09

2. Chen Y, Liu O, Guo D. Emerging coronaviruses: genome structure, replication, and pathogenesis. J Med Virol. 2020;92(4):418-423. doi:10.1002/jmv.25681

3. Backer JA, Klinkenberf D, Wallinga J. Incubation period of 2019 novel coronavirus (2019-nCov) infections among travellers from Wuhan, China. Eurosurveillance. 2020;25:20-28. doi:10.2807/15607917.ES.2020.25.5.2000062

4. Guan WJ, Ni ZY, Hu Y, et al. Clinical characteristics of coronavirus disease 2019 in China. $N$ Engl J Med. 2020;382(18):1708-1720. doi:10.1056/NEJMoa2002032

5. Chan JF, Yuan S, Kok KH, et al. A familial cluster of pneumonia associated with the 2019 novel coronavirus indicating person-toperson transmission: a study of a family cluster. Lancet. 2020;395 (10223):514-523. doi:10.1016/S0140-6736(20)30154-9

6. Zhang Z, Liu S, Xianf M, et al. Protecting healthcare personnel from 2019-nCov infection risks: lessons and suggestions. Front Med. 2020;1-3.

7. Cleveland JL, Gray SK, Harte JA, et al. Transmission of blood borne pathogens in US dental health care settings. $J$ Am Dent Assoc. 2016;147:729-738. doi:10.1016/j.adaj.2016.03.020

8. To KK, Tsang OT, Chik-Yand Yip C, et al. Consistent detection of 2019 novel coronavirus in saliva. Clin Infect Dis. 2020;149:1093.

9. Samaranayke LP, Peiris M. Severe acute respiratory syndrome and dentistry. A retrospective view. $J$ Am Dent Assoc. 2004;135 (9):1292-1302. doi:10.14219/jada.archive.2004.0405

10. Harrel SK, Molinau J. Aerosols and splatter in dentistry: a brief review of literature and infection control implications. $J$ Am Dent Assoc. 2004;135:429-437. doi:10.14219/jada.archive.2004.0207

11. Halepas S, Femini EM. A punch of prevention is a worth pound of cure. Proactive dentist in the wake of COVID-19. J Oral Maxillofac Surg. 2020;78(6):860-861. doi:10.1016/j.joms.2020.03.036

12. Hau YS, Kim JK, Hur J, Chang MC. How about actively using telemedicine during the COVID-19 pandemic. J Med Syst. 2020;44 (6):108. doi:10.1007/s10916-020-01580-z

13. Shancham M, Raz H, Kolerman R, Mijiritsky O, Ben-Ezra M, Mijiritsky E. COVID 19 factors and psychological factors associated with elevated psychological distress among dentists and dental hygienists in Israel. Int J Environ Res Public Health. 2020;17(8):2900. doi:10.3390/ijerph 17082900

14. Ahmed MA, Jouhar R, Ahmed N, et al. Fear and practice modifications among dentists to combat novel coronavirus disease (COVID-19) outbreak. Int J Environ Res Public Health. 2020;17 (8):17082821. doi:10.3390/ijerph17082821

15. Gamio L The worker who face the greatest corona risk. Available from: http://www.nytimes.com/interactive/2020. Accessed June 1, 2020.
16. Al-Shawi MM, Darwish MA, Wahab A, Al-Shamlan NA. Misconceptions of parents about antibiotic use in upper respiratory tract infections: a survey in primary schools of the Eastern Province, KSA. J Fam Community Med. 2018;25:5-12.

17. Peng X, Xu X, Li Y, et al. Transmission routes of 2019-nCoV and controls in dental practice. Int J Oral Sci. 2020;12(1):9. doi:10.1038/ s41368-020-0075-9

18. Meng L, Hua F, Bia Z. Coronavirus disease 2019. COVID-19 Emerging future challenges for dental and oral medicine. $J$ Dent Res. 2020;99(5):481-487. doi:10.1177/0022034520914246

19. Kamate S, Sharma S, Thakar S, et al. Assessing knowledge, attitudes and practices of dental practitioners regarding the COVID-19 pandemic: a multinational study. Dent Med Problem. 2020;57(1):11-17. doi:10.17219/dmp/119743

20. Putrino A, Raso M, Magazzino C, et al. Coronavirus (COVID-19) in Italy: knowledge, management of patients and clinical experience of Italian dentists during the spread of contagion. BMC Oral Health. 2020;20(1):200. doi:10.1186/s12903-020-01187-3

21. Quadri MFA, Jafer MA, Alqahtani AS, et al. Novel corona virus disease (COVID-19) awareness among the dental interns, dental auxiliaries and dental specialists in Saudi Arabia: a nationwide study. J Infect Public Health. 2020;13(6):856-864. doi:10.1016/j. jiph.2020.05.010

22. Sohrabi C, Alsafi Z, O’Neill N, et al. World Health Organization declares global emergency: a review of the 2019 novel coronavirus (COVID-19). Int $J$ Surg. 2020;76:71-76. doi:10.1016/j. ijsu.2020.02.034

23. WHO director-general's opening remarks at the media briefing on COVID-19-3 March 2020. Available from: https://www.who.int/dg/ speeches/detail/who-director-general-s-opening-remarks-at-themedia-briefing-on-covid-19-3-march-2020. Accessed June 1, 2020.

24. Roser M, Ritchie H, Ortiz-Ospina E, et al. Mortality risk of COVID-19; 2020. Available from: https://ourworldindata.org/mortal ity-risk-covid. Accessed June 1, 2020.

25. Tahamtan A, Ardebili A. Real-time RT-PCR in COVID-19 detection: issues affecting the results. Expert Rev Mol Diagn. 2020;20(5):453454. doi:10.1080/14737159.2020.1757437

26. Rothe C, Schunk M, Sothmann P, et al. Transmission of 2019-nCoV infection from an asymptomatic contact in Germany. $N$ Engl $J$ Med. 2020;382:970-971. doi:10.1056/NEJMc2001468

27. De Stefani A, Bruno G, Mutinelli S, Gracco A. COVID-19 outbreak perception in Italian dentists. Int J Environ Res Public Health. 2020;17:3867. doi:10.3390/ijerph17113867

28. Cagetti MG, Cairoli JL, Senna A, Campus G. COVID-19 outbreak in North Italy: an overview on dentistry. A questionnaire survey. Int J Environ Res Public Health. 2020;17(11):3835. doi:10.3390/ ijerph17113835

29. Occupational Safety and Health Administration's Guidance on Preparing Workplaces for COVID-19. Available from: OSHA399003 2020. Accessed June 1, 2020.

30. van Doremalen N, Bushmaker T, Morris DH, et al. Aerosol and surface stability of $\mathrm{HCoV}-19$ (SARS-CoV-2) compared to SARS-CoV-1. $\quad N \quad$ Engl $J \quad$ Med. 2020;382(16):1564-1567. doi:10.1056/NEJMc2004973

31. Khader Y, Al Nsour M, Al-Batayneh OB, et al. Dentists' awareness, perception, and attitude regarding COVID-19 and infection control: A cross- sectional study among Jordanian dentists. JMIR Public Health Surveill. 2020;6(2):e18798. doi:10.2196/18798

32. Centers for Disease Control and Prevention. Infection control: severe acute respiratory syndrome coronavirus 2 (SARS-CoV-2). Available from: https://www.cdc.gov/coronavirus/2019-ncov/infection-control /controlrecommendations.html. Accessed June 1, 2020.

33. Centers for Disease Control and Prevention. Dental settings: interim infection prevention and control guidance for dental settings during the COVID-19 response. Available from: https://www.cdc.gov/coro navirus/2019-ncov/hcp/dental-settings.html. Accessed June 1, 2020. 
34. Centers for Disease Control and Prevention: interim Infection Prevention and Control Recommendations for Patients with Suspected or Confirmed Coronavirus Disease 2019 (COVID-19) in Healthcare Settings. Available from: https://www.cdc.gov/corona virus/2019-ncov/hcp/infection-control-recommendations.html\#take_ precautions. Accessed June 1, 2020.

35. World Health Organization. Clinical management of severe acute respiratory infection when novel coronavirus (2019-nCoV) infection is suspected: interim guidance; 2020a. Available from: https://www. who.int/publications-detail/clinical-management-of-severe-acuterespiratory-infection-when-novel-coronavirus-(ncov)-infection-issuspected. Accessed June 1, 2020.

36. Marui VC, Souto MLS, Rovai ES, Romito GA, Chambrone L, Pannuti CM. Efficacy of preprocedural mouthrinses in the reduction of microorganisms in aerosol: a systematic review. $J$ Am Dent Assoc. 2019;150(12):1015-1026. doi:10.1016/j.adaj.2019.06.024
37. Eggers M, Koburger-Janssen T, Eickmann M, Zorn J. In vitro bactericidal and virucidal efficacy of povidone-iodine gargle/mouthwash against respiratory and oral tract pathogens. Infect Dis Ther. 2018;7:249-259. doi:10.1007/s40121-018-0200-7

38. Centers for Disease Control and Prevention: infection control basics, Transmission Based Precautions. Available from: https://www.cdc. gov/infectioncontrol/basics/transmission-basedprecautions.html\#an chor_1564058235. Accessed June 1, 2020.

\section{Publish your work in this journal}

The Journal of Multidisciplinary Healthcare is an international, peerreviewed open-access journal that aims to represent and publish research in healthcare areas delivered by practitioners of different disciplines. This includes studies and reviews conducted by multidisciplinary teams as well as research which evaluates the results or conduct of such teams or healthcare processes in general. The journal covers a very wide range of areas and welcomes submissions from practitioners at all levels, from all over the world. The manuscript management system is completely online and includes a very quick and fair peer-review system. Visit http://www.dovepress.com/testimonials. php to read real quotes from published authors. 